\title{
The Influence of Cost of Equity on Financial Distress and Firm Value
}

\author{
Anna Sumaryati \\ Faculty of Economic and Business \\ University of Dian Nuswantoro \\ Semarang, Indonesia \\ annasumaryati@yahoo.co.id
}

\author{
Nila Tristiarini \\ Faculty of Economic and Business \\ University of Dian Nuswantoro \\ Semarang, Indonesia \\ nila.tristiarini@dsn.dinus.ac.id
}

\begin{abstract}
Cost of equity is the cost incurred by the company to meet the rate of return expected by investors, either in the form of dividends or capital gains Since investors wanted a rate of return on the investment, then the company should compensate the shareholders with the economic return implicit in forecasting in the future, which may be different from the previous performance. The company's incapability in controlling the cost of equity can increase the occurrence of financial distress, which in turn can decrease the firm value. The purpose of this research is to find out whether the cost of equity can influence the occurrence of financial distress, which suffers a substantial reduction in firm value. The research variables are cost of equity as an independent variable, Financial distress as a mediator and Firm Value as an independent variable. The population of the research is the go public companies in the corporate governance perception index ranking by Corporate Forum for Governance in Indonesia. The sample selection of the study using the purposive sampling method so that the number of samples is 144 companies. The result shows that the cost of equity has a significant effect on financial distress and Firm Value, but the financial distress doesn't affect firm Value.
\end{abstract}

Keywords-Cost of Equity, Financial Distress, Firm Value

\section{INTRODUCTION}

Company value is very important because it reflects the success in maximizing goals, this is indicated by increasing prosperity for investors. Company goals are clearly planned. Company value is a proxy reflect shareholder wealth [1]. The value of the firm can give maximum shareholder wealth if the stock price increases. The more increase the stock price of a company, then the maximum shareholder wealth also. According to Nurlela and Islahuddin [2], Enterprise Value (EV) or also known as firm value is an important concept for investors is an indicator in determining the value of the company. Company value is the price willing to be paid by prospective buyers if the company it is sold.

Firm value is influenced by several factors. In this study cost of equity is considered to influence Firm Value. The cost of equity is the cost incurred by the company to meet the expected rate of return by investors, either in the form of dividends or capital gains. This shows that the greater the cost of capital the greater the fulfillment of the return rate for investors. This will lead to a positive response from investors to increase the firm's value.
[3] argues that the stock market price the market price reflects the value of the company, and explains that to maximize the value of the company not only with the value of equity alone that must be considered, but also all financial resources such as debt, warrants and preferred stock.

[4] argue that the optimization of firm value is a corporate goal can be achieved through the function of financial management and a financial decision taken will affect other financial decisions and impact on the value of the company. The market value of the firm is the market value of a firm's equity plus the market value of the debt [5]. Thus, the addition of the company's equity amount to its debt can reflect the value of the firm. Based on previous research, there are several factors that can affect the value of the company including funding decisions, dividend policy, investment decisions, capital structure, cost of equity and financial distress.

Capital structure theory explains the effect of capital structure on firm value. Company value can be interpreted as expectation of shareholder investment value (equity market price) and / or expectation of total company value (equity market price added with market value of debt, or market price of asset expectation) [6] Research on capital structure influencing value the company has done a lot in Indonesia. One of these researchers is [6] found evidence that the capital structure had an indirect effect negative to firm value. Based on the empirical facts in his research explaining that in times of crisis, market participants understand that the increase in debt is caused by external factors (foreign exchange rates and interest rates) that can not be controlled by the company. Market participants are confident that if these external influences return to normal, then the company will recover, and the market value of equity is determined by demand and supply. Costs incurred by the company to be expected by investors, either in the form of dividends or capital gains.

[7] Proves that Cost Of Equity directly affects the value of the company and indirectly the investment decision affects the value of the company through dividend policy and funding decision. Who examined the relationship of capital structure to firm performance in the banking industry, classified banks based on shareholding structure. [8] [13] Prove that $\mathrm{COE}$ affects FV, while [9] argues that $\mathrm{COE}$ has a 
weak relationship with $\mathrm{FV}$; [10] prove that $\mathrm{COE}$ does not influence with FV.

[11] Use the assumption of ignoring the FD, the thing that causes the company to get as much debt as possible to get maximum firm value, whereas empirically the company trends to have reasonable debt. This research tries to use Financial distress connecting COE and FV. FD is a condition in which the operating results of the company can not fulfill the obligations before liquidation [12]. If a corporation with high COE causes a high level of financial difficulty that will affect the stock price (FV). This causes FD to mediate the relationship between $\mathrm{COE}$ and $\mathrm{FV}$.

\section{LITERATURE REVIEW}

\section{A. Impact Cost of Equity on Firm Value}

Capital cost is the cash flow that is available to the resource provider after paying all costs and business requirements necessary to maintain it in the form of an operation. Cost Of Equity impact on revenue and profitability of company which will increase Firm Value. Some research on COE with FV such as [8][13] proves that COE affects FV. It is in line with Capital Structure Theory proposed by [14] about the COE effect on FV.

$\mathrm{H} 1$ = Cost of Equity effect on Firm Value

\section{B. Impact Cost Of Equity on Financial Distress}

Companies experiencing financial difficulties can reduce the cost of equity. If the capital cost incurred by a large corporation will result in financial difficulties as the money spent on the cost of equity increases. Research [15] [19] show that COE has influences FV. With large capital expenditures then the company will tend to experience financial difficulties. Because some current assets are used to pay dividends and profits High COE levels in the firm's capital structure also increase the risk of financial difficulties. The company's financial difficulties resulted from the company having to fulfill its obligations to fulfill its financial obligations in the form of dividends or profits. The risk of bankruptcy forces managers to work in an efficient manner that increases the profitability of a company or [12] argues that to avoid FD the firm needs to reduce its Cost of Equity.

Companies with financial difficulties will have an effect managers can lose jobs before the company is liquidated. Managers have a risk of losing their jobs so they take advantage of company resources in positive NPV projects rather than throw them in their interest activities.

$\mathrm{H} 2=$ Cost Of Equity effect on Financial Distress

\section{Impact of Financial Distress on Firm Value}

Financial Distress deals with broad concepts with some situations where companies face financial difficulties. The general situation is what determines financial difficulties. Including bankruptcy [14] [16] define financial difficulties as a situation that affects companies in a state of uncertainty [17] relate financial difficulties to situations in which firm contracts with a creditor in return for profit or dividend.

Modigliani \& Miller argued that the funding decision would ignore the FD. This is because the company uses the assumption of going concern, although in reality FD often happens that caused the management of corporate financial less good, resulting in FD which ultimately can reduce the value of the company.

H3 = Financial Distress affect Firm Value

\section{Financial Distress Mediating Relationship Cost of Equity with Firm Value}

Financial difficulties will affect managers in determining whether to obtain funds from investors or creditors. The policy of obtaining capital from investors has the effect of disciplining manager behavior in returns in the form of dividends or profits. Fulfillment of excessive capital while poor management will result in a large capital cost (COE) that will result in the company unable to Fulfill short-term and long-term liabilities. It indicates that the company has experienced financial distress that can ultimately reduce the value of the company.

Concerns of financial distress resulting from over-expense of equity expenses will result in a decrease in firm value.

\section{H4 = Financial Distress Mediating Relationship Cost Of Equity with Firm Value}

\section{RESEARCH METHOD}

The population is all publicly listed companies that are included in the ranking of corporate governance perception index by Forum for Corporate Governance in Indonesia starting from 2011-2015 observation year. Selection of sample research using purposive sampling method so that the number of samples of 144 companies.

Exogenous variable in this research is Cost of Equity (COE). COE is the cost incurred by the company to meet the expected returns by investors, either in the form of dividends or capital gains. In this study $\mathrm{COE}$ is calculated in the following way:

Cost of Equity $=\frac{\text { Earning After Tax }}{\text { Total Equity }}$

Endogen Variable in this research is Firm Value (FV) is a perception of an investor to company which often associated with stock market price. When the Company is liquidated, the shareholder will earn a share value amount market price. So the value of book value is very meaningful to see the return on investment. Thus, it can be concluded that FV can be measured by PBV which is one of the main indicators to know the stock price is high or not. FV in this study was measured using Price Book Value (PBV). PBV can be measured by the following formula:

$$
\text { PBV }=\frac{\text { Stock Price }}{\text { Book Value }}
$$


Variable Mediation in this research is Financial Distress (FD). FD is a condition where the company's cash flow operation is not sufficient to meet current obligations. To calculate FD, this research uses the following formula:

$$
\mathrm{S}=1.03 \mathrm{~A}+3.07 \mathrm{~B}+0.66 \mathrm{C}+0.4 \mathrm{D}
$$

Where:

$$
\begin{aligned}
& \mathrm{S}=\text { Financial Distress } \\
& \mathrm{A}=\text { Working capital/Total asset; } \\
& \mathrm{B}=\text { Net profit before interest and taxes/Total Asset } \\
& \mathrm{C}=\text { Net profit before taxes/Current liabilities; } \\
& \mathrm{D}=\text { Sales/Total asset }
\end{aligned}
$$

This research uses Structural Equation Modeling (SEM) analysis tool with WarpPLS version 3.00 program used to test a hypothesis. This statistical analysis tool is chosen because it has several advantages that can perform statistical tests with mediating variables without the need to do repetitive testing to be able to answer the hypothesis. This analysis tool is designed to solve problems such as small sample size, multivariate nondistributed data, missing values, and multi coloniality among exogenous variables [18]. The research framework can be illustrated using the analytical path in figure 1 :

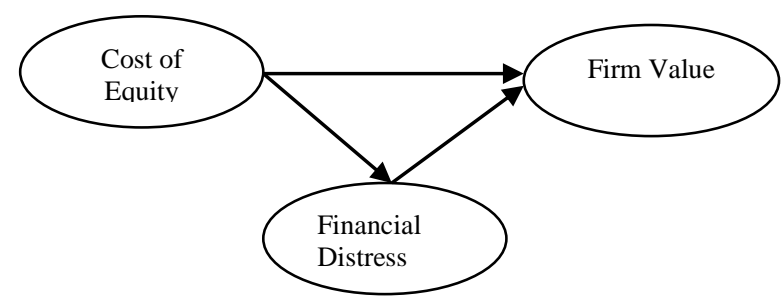

Figure 1. Conceptual Research Framework

\section{RESULT AND DISCUSSION}

\subsection{Descriptive Statistics}

Descriptive statistics are used to explain the characteristics of research variables used. Therefore the explanation of descriptive statistics of research variables are as follows :

Table 1. Descriptive Statistics of Research Variables

\begin{tabular}{|l|c|r|r|r|r|}
\hline Variable & N & \multicolumn{1}{|c|}{ Min } & \multicolumn{1}{c|}{ Max } & \multicolumn{1}{c|}{ Mean } & \multicolumn{1}{c|}{$\begin{array}{c}\text { Std. } \\
\text { Deviation }\end{array}$} \\
\hline COE & 144 & 0,0090 & 1,2581 & 0,2264 & 0,2063 \\
\hline FD & 144 & 0,3763 & 14,0776 & 2,3196 & 1,4481 \\
\hline FV & 144 & 0,0900 & 46,6330 & 3,1335 & 5,3280 \\
\hline
\end{tabular}

Source: Processed data used in this study; COE: Cost of Equity; FD: Financial Distress; FV: Financial Value

From table 1 the descriptive statistics of the research variables show that the COE variable has an average of 0.2264 with a standard deviation of 0.2063 . The average value for FD is 2.3196, with a standard deviation of 1.4481. While the average value of Firm Value of 3.1335 with a standard deviation of 5.3280 .

\subsection{Hypothesis Testing}

To be able to answer the hypothesis of mediation of research it must be done first making direct path analysis that describes the relationship of causality between exogenous variable that is Cost Of Equity with endogen variable is Firm Value. So after run-test obtained direct path analysis in Figure 2:

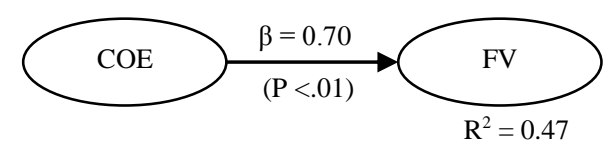

Figure 2. Direct Path Analysis

Source: Processed data used in this study

From Figure 2 above shows the causal relationships between variables, namely Cost of Equity as exogenous to Firm Value as an endogenous variable, and which has the path coefficient value of 0.70 with a p-value $(<0: 01)$. Firm Value has a $\mathrm{R}$ square value of 0.47 .

Furthermore, the full path analysis is tested to be able to answer the next hypothesis, especially to prove the hypothesis testing of mediation. Testing is done by testing the causal relationship between exogenous variables (Cost of Equity), mediating variables (Financial Distress) and endogenous variables (Firm Value). The results of the full path analysis can be illustrated in Figure 3 below:

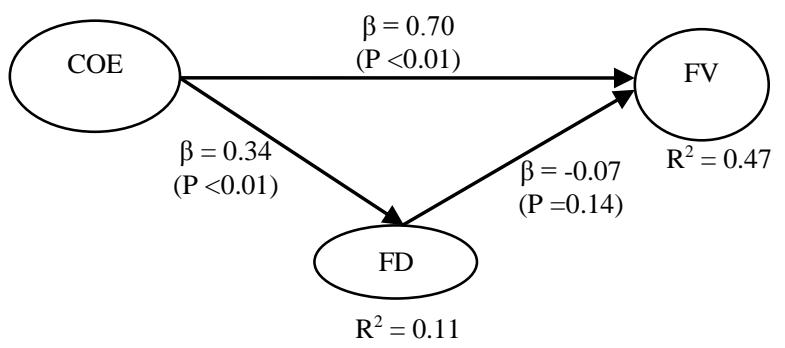

Figure 3. Full Path Analysis

From Figure 3 above, showing the causality relationship between variables, namely Cost of Equity as exogenous variables with Firm Value as endogenous variable, and Financial Distress mediation variables, which have coefficient path value between Cost of equity with Firm Value of 0.70 with p-value $<0.01$. The coefficient path value between Cost of Equity and Financial Distress is 0.34 with p-value $<0,01$. While the value of the path coefficient between FD with Firm Value of 0.07 with $\mathrm{p}$-value $=0.14$. Leverage has a $\mathrm{R}$ square value of 0.11 . Firm Value has a $\mathrm{R}$ square value of 0.47

The results of Path coefficients and $P$ values to see the magnitude of coefficient and significance level are as follows: 
Table 2. Path coefficients Result and $P$ value

\begin{tabular}{|l|r|r|r|r|}
\hline \multirow{2}{*}{ Path } & \multicolumn{2}{|c|}{ Direct Effect } & \multicolumn{2}{c|}{ Indirect Effect } \\
\cline { 2 - 5 } & Koefisien & P-Value & Koefisien & P-Value \\
\hline COE $\rightarrow$ FV & 0.47 & $<0.01$ & 0.70 & $<0.01$ \\
\hline COE $\rightarrow$ FD & & & 0.34 & $<0.01$ \\
\hline FD $\rightarrow$ FV & & & -0.07 & $=014$ \\
\hline
\end{tabular}

Source: Processed data used in this study; COE: Cost of Equity; FD: Financial Distress; FV: Financial Value

From Table 2 shows the test results that the COE direct effect coefficient to PV is 0.70 and significant at $p<0.01$. So it can be concluded that the first hypothesis (H1) accepted that the Cost Of Equity significant effect on Firm Value. These results indicate that the first requirement to be a mediating variable is the coefficient of $\mathrm{COE} \rightarrow \mathrm{FV}$ is significant.

The result of indirect effect indicates that coefficient of COE path to FD is equal to 0,34 and significant at $p<0,01$. So it can be concluded that the second hypothesis (H2) accepted that the Cost of Equity significant effect on Financial Distress. These results indicate that the requirement to be a mediating variable is met i.e., the coefficient of $\mathrm{COE} \rightarrow \mathrm{FV}$ is significant. Furthermore, the coefficient of FD path to FV is -0.07 and not significant at $\mathrm{p}=0.14$. So it can be concluded that the third hypothesis (H3) is not accepted that the FD has no significant effect on Firm Value. These results indicate that the requirement to be the mediation variable is not fulfilled ie, the coefficient of FD $\rightarrow$ FP is not significant.

The result of COE test to FV shows that the direct effect coefficient is 0.70 and significant $p<0.01$. While COE indirect effect coefficient to FV decreased to 0.70 from 0.47 but not significant. These results indicate that FD is not a mediation. Then it can be concluded that the fourth hypothesis (H3) is rejected that FD has not been proven to mediate the relationship of COE with Firm Value.

\subsection{Discussion}

The results of this study indicate that the Cost of Equity significantly influences the financial distress. This shows that the cost of equity can be controlled properly will increase the firm value because it illustrates the greater the fulfillment of the rate of return on investors. The results also show that Financial Distress is not a mediation variable on the relationship of cost of equity with firm value. This means that although cost of equity is a cost if the cost can be controlled for the investor's tie will not cause financial distress.

\section{CONCLUSION AND IMPLICATION}

The results show that Cost Of Equity can affect Financial Distress and Firm Value but cannot prove Financial Distress as a mediation between Cost Of Equity with Firm Value. This shows that the utilization of Cost Of Equity can be used for shareholders to measure manager's performance in maximizing shareholder's profit. The implication of this research is to give conceptual new science about Cost Of Equity strategy that can increase Firm Value.

\section{References}

[1] Sartono, A., "Manajemen Keuangan : Teori dan Aplikasi," Edisi 4, Yogakarta, 2010.

[2] Nurlela and Islahuddin, "Pengaruh Corporate Social Responsibility Terhadap Nilai Perusahaan Dengan Prosentase Kepemilikan Manajemen Sebagai Variabel Moderating (Studi Empiris Pada Perusahaan Yang Terdaftar Di Bursa Efek Jakarta). Simposium Nasional Akuntansi XI 2324 Juli 2008. Pontianak.

[3] Fama, F Eugene, "The Effects of a Firm's Investment and Financing Decision on The Welfare of its Security Holders," The American Economic's Review, Vol.68. No.3, 1978, pp 272-284.

[4] Fama, F Eugene, and Kenneth R French, "Value versus Growth: The International Evidence," The Journal Finance, 1998, Vol L III. No.6.

[5] Helfert, Erich A., "Teknik Analisis Keuangan," Terjemahan, Herman Wibowo, Edisi kedelapan. Erlangga, 1997, Jakarta.

[6] Sugihen, S.G., "Pengaruh Struktur Modal Terhadap Produktivitas Aktiva, Kinerja Keuangan, Serta Nilai perusahaan Industri Manufaktur Terbuka Di Indonesia," 2003, Disertasi.

[7] Hasnawati, Sri., "Dampak Set Peluang Investasi Terhadap Nilai Perusahaan Publik di Bursa Efek Jakarta," Jurnal Akuntansi dan Auditing.Indonesia. Vol, 9. No. 2, 2005, pp. 117-126

[8] Nor Edi Azhar Binti and Noriza Binti Mohd SAAD, "Cost of Capital- The Effect to Firm Value and Profitability Performance in Malaysia," International Journal of Academic Research in Accounting, Finance and Management Sciences, Volume 2, Issue 4, 2012.

[9] Botosan, Christine, A., "Disclosure Level and The Cost of Equity Capital.” The Accounting Review, 1997, pp. 323.

[10] Dhankar Raj, R., and Boora, A., Jit, S., "Cost of Capital, Optimal Capital Structure, and Value of Firm: An Empirical Study of Indian, SAGE Journal, Vol. 21, No. 3, July-September 1996. pp. 29-36.

[11] Modigliani, F and Miller, M., H., "The Cost of Capital, Corporation Finance a and the Theory of Investment," American Economic Review, 48, 1958, pp 261-97

[12] Platt, H. and Plat, M., "Predicting Corporate Financial distress: Reflection on Choice -Based Sample Bias," Journal of Economics and Finance, Vol. 26 (2), Summer, 2002, pp. 184-199.

[13]Muhammad Shadab Abdul Sattar., "Cost of Capital - The Effect to the Firm Value and Profitability;Empirical Evidences in Case of Personal Goods (Textile) Sector of KSE 100 Index," Journal of Poverty, Investment and Development.Vol.17, 2015, pp. 24-28.

[14] Maina, F. G. and Sakwa, M. M., "Understanding Financial Distress among Listed Firms in Nairobi Stock Exchange: A Quantitative Approach Using the Z-Score Multi-Discriminant Financial Analysis Model,” Jomo Kenyatta University of Agriculture and Technology, Nairobi, Kenya, 2012.

[15] Hoshi, Tokeo., Kashyap, Anil., and Scharfstein, David., "The Role of Banks in Reducing The Costs of Financial Distress in Japan," Journal of Financial Economics, Vol. 27, 1990, pp. 67-88.

[16] Duda, M., and Schmidt, H., "Bankruptcy Prediction: Static Logic Model versus Discrete Hazard Models Incorporating Macroeconomic Dependencies, Lund University, 2010.

[17] Senbet, L. W. and Wang, T. Y., "Corporate Financial Distress and Bankruptcy: A Survey. Foundations and Trends in Finance," Forthcoming, 2012.

[18] Latan, H., and Ghozali, I. (2012).Partial Least Squares "Konsep, Metode dan Aplikasi" menggunakan program WarpPLS 3.0. Semarang: Badan Penerbit Universitas Diponegoro

[19] Richard B., Whitaker, "The Early Stage of Financial Distress," Journal of Economics and Finance, Vol. 23. no.2, 1999, p.123-133 